\title{
Diseases Resistance in Potato: Genetic Resources Respond to Bacterial Wilt and Viral Diseases Complex
}

\author{
Pravin Kumar Sharma ${ }^{1}$ and Narendra Lakpale $^{2 *}$ \\ ${ }^{1}$ Department of Vegetable Science, ${ }^{2}$ Department of Plant Pathology, Indira Gandhi Krishi \\ Vishwavidyalaya, Raipur (C.G), India \\ *Corresponding author
}

\section{A B S T R A C T}

Keywords

Bacterial wilt,

Ralstonia

solanacearum,

Viral diseases,

Potato

Article Info

Accepted:

15 March 2020

Available Online:

10 April 2020
The evaluation study was conducted for different potato varieties and local genotypes collected from different parts of Chhattisgarh and screened against bacterial wilt and viral diseases complex. The locally collected genotypes have been further categorized on the basis of their distinct growth, yield, quality and disease and insect pest reactions behaviour. The study was carried-out at Department of Vegetable Science, IGKV, Raipur, Chhattisgarh in consecutive years i.e. 2013-14 to 2018-19. The genotypes were screened under bacterial wilt-sick plot condition and recurrent seed tubers material were utilised to evaluate the latent infection of disease. The disease incidence was recorded among the 20 genotypes/varieties and among them local collection showed extremely low bacterial wilt incidence ranged from $0.10-7.41 \%$. The wilt incidence was recorded $0.1 \%$ with genotypes IGP $2012-1$ and $1.50 \%$ in IGP $2012-5$ followed by IGP $2012-7(0.74 \%)$, IGP-2012-2 (1.48\%), IGP-2012-6 (2.22\%), IGP 2012-4 (6.30\%) and IGP 2012-4 (7.41\%). Among the released varieties, wilt incidence was ranged from $10.30 \%$ (Kufri Jyoti) to $41.74 \%$ (Kufri Pukhraj). The genotype IGP 2012-2 was recorded most promising as recorded $1.48 \%$ bacterial wilt infection and $10 \%$ viral disease incidence $(90 \%$ resistance against virus diseases complex).

\section{Introduction}

Cultivated potatoes (Solanum tuberosum L.) domesticated from wild Solanum species native to the Andes of southern Peru, possess a diverse gene pool. Despite its importance, potato genetic diversity at the whole-genome level remains largely unexplored. Worldwide, potato is the third most important crop grown for direct human consumption. It is one of the most important vegetable and economical food crops in India as well as many countries of the world. It is considered to be the "King of Vegetables", because of its greater utility, It occupies a pre-eminent place amongst the crops. India produced 46546 thousand tonnes from 2164 thousand ha with an average yield of 24.4 t/ha (Anon., 2017). India is world's second largest producer of potato next to China (Anon, 2017a). 
To feed this ever growing human population there is a need to increase productivity of every food crop and also of potato. Potato is mainly grown for its valued tubers. Tuber yield is a complex character associated with many interrelated components, the cumulative effect of many components individually contributing towards tuber yield. Looking to the need the most significant potato breeding objective it is higher yield of quality produce.

Ralstonia solanacearum is the causal agent of the disease known as potato brown rot or bacterial wilt (BW). Bacterial wilt is the second most important constraint to potato production in tropical and subtropical regions of the world after late blight. The disease has been estimated to affect about 1.7 million ha.in approximately 80 countries worldwide, with global damage estimates of over 950 million USD per annum (Champoiseau et al., 2009). This disease has no effective means of control because crop protection chemicals and biological are ineffective and expensive (Smith et al., 1998; Champoiseau et al., 2010). Cultural methods such as crop rotations are largely impractical because the farms are too small to allow effective rotation. The bacterium affects more than 30 plant species, the most susceptible crops being potato, tomato, eggplant, pepper, banana and groundnut. Spread of the pathogen worldwide has been associated with its dissemination in latently infected planting material and it persists for along time in the soil (Kaguogo et al., 2008; Muthoni et al., 2010). Quarantine measures necessary to avoid spread of the disease to $\mathrm{BW}$-free areas often restrict the production of seed potatoes and limit the commercialization of potatoes between countries and between infected and noninfected regions within a country.

Potato viruses are serious problem, not only because of effects caused by primary infection, but also because the crop is vegetatively propagated and they are transmitted through the tubers to subsequent vegetative generations. The level of virus infection has also increase in successive generations of seed potato. Viruses transmission through seed tubers from generation to generation is a major limitation of potato seed tuber production and yield depletion. Among the viral diseases, mosaic, stunting, necrosis and leaf roll are most important and caused by several viruses i.e. Potato Virus X (PVX), Potato Virus Y (PVY), Potato Virus A (PVA), Potato Virus S (PVS), Potato Virus M (PVM), mop-top virus, potato aucuba virus, potato leaf roll virus (PLRV) and potato apical leaf roll virus (APLRV) these are almost found in all potato growing zones of India (Uniyal, 2003). Insects (aphid, whitefly, leaf hopper and beetle), fungi and seeds serve as primary source and vector for virus transmission Paul and Konar (2003). Potato virus $\mathrm{Y}$ and leaf roll may cause $60-75$ per cent tuber yield loss while potato virus $\mathrm{X}$, $\mathrm{S}, \mathrm{A}$ and $\mathrm{M}$ may decreases tuber yields by 10 30 per cent (Khurana and Singh, 1988; Khurana and Garg, 1992). Continuous use of old infected seed stocks up to 3-4 years bringing down their yielding ability to almost 50 per cent (Nagaich et al., 1974; Khurana and Singh, 1988; Khurana and Garg, 1992).

Development of resistant cultivars is currently the best approach for managing bacterial wilt as well as viral disease complex, however, there are no known potato cultivars with these resistance. The resistance has been shown are very unstable due to its strong host-pathogenenvironment interaction (Tung 1992). Due to these, an essential step in theresistant varietal development is screening of potato germplasm at the target environment to identify promising clones for breeding programme.

Screening of the clones for resistance under local environmental conditions is the first important step for effective resistance breeding. This study was carried out to determine the reaction to bacterial wilt of the 
potato genotypes currently grown by local farmers in Chhattisgarh as well as other clones from CPRI, Shimla so as to identify parents that can be used in the local breeding program to develop resistant cultivars.

\section{Materials and Methods}

Twenty genotypes including released varieties of Potato were evaluated for bacterial wilt as well as virus disease complex resistance at Department of Vegetable Science, IGKV, Raipur, Chhattisgarh from 2013-14 to 201819. Local genotypes collected from different parts of Chhattisgarh and released varieties were planted in separate plots of $2.4 \times 2.0 \mathrm{~m}$. Each plot having four rows of 40 plants. The locally collected genotypes were further categorized on the basis of differentiable characteristics viz., distinct plant growth, yield, quality and disease reactions. The genotypes were also screened under bacterial wilt affected plot condition. Planted recurrent seed tubers material to evaluate the latent infection of disease. The disease incidence was recorded 60 days after planting. The experiment was conducted according to recommended package and practices.

\section{Results and Discussion}

Among the different genotypes maximum plant height of $55.53 \mathrm{~cm}$ was recorded in IGP 2012-3 followed by IGP 2012-1 $(52.25 \mathrm{~cm})$ and IGP 2012-7 (48.08 cm). The yield performance recorded higher in K. Surya (30.19 t/ha) followed by Khyati (28.67 t/ha) and Pukhraj and Garima (28.17 and 26.43 t/ha, respectively) (Table 1).

Table.1 Performance of different potato varieties/genotypes against bacterial wilt and viral diseases

\begin{tabular}{|c|c|c|c|c|c|}
\hline S.No. & Entry & $\begin{array}{c}\text { Plant height } \\
(\mathrm{cm})\end{array}$ & $\begin{array}{l}\text { Total tuber } \\
\text { yield (t/ha) }\end{array}$ & $\begin{array}{l}\text { Plant mortality by } \\
\text { bacterial wilt }(\%)\end{array}$ & $\begin{array}{l}\text { Viral Diseases } \\
\text { Incidence }(\%)\end{array}$ \\
\hline 1. & K. Jyoti & 34.00 & 26.34 & 10.30 & 66.52 \\
\hline 2. & K. Surya & 36.77 & 30.19 & 18.89 & 75.00 \\
\hline 3. & K. Khyati & 41.12 & 28.67 & 33.33 & 81.44 \\
\hline 4. & K. Pukhraj & 31.09 & 28.17 & 41.74 & 79.80 \\
\hline 5. & K. Garima & 34.56 & 26.43 & 32.96 & 68.56 \\
\hline 6. & K. Sindhuri & 33.22 & 24.51 & 15.93 & 71.36 \\
\hline 7. & Atlantic & 38.63 & 16.38 & 41.48 & 87.74 \\
\hline 8. & K. Mohan & 39.18 & 22.59 & 36.67 & 73.89 \\
\hline 9. & K. Lalit & 36.27 & 28.34 & 31.85 & 71.19 \\
\hline 10. & K. Ashoka & 32.48 & 23.56 & 17.03 & 74.66 \\
\hline 11. & K. Chipsona-1 & 33.83 & 20.19 & 12.34 & 83.44 \\
\hline 12. & K. Bahar & 36.61 & 22.41 & 20.74 & 74.19 \\
\hline 13. & K. Arun & 35.15 & 21.34 & 18.43 & 74.36 \\
\hline 14. & IGP 2012-1 & 52.25 & 14.81 & 0.10 & 35.00 \\
\hline 15. & IGP 2012-2 & 34.77 & 15.37 & 1.48 & 10.00 \\
\hline 16. & IGP 2012-3 & 55.53 & 12.09 & 6.30 & 73.28 \\
\hline 17. & IGP 2012-4 & 32.15 & 22.47 & 7.41 & 76.65 \\
\hline 18. & IGP 2012-5 & 37.17 & 18.64 & 0.50 & 43.20 \\
\hline 19. & IGP 2012-6 & 33.50 & 16.37 & 2.22 & 67.63 \\
\hline 20. & IGP 2012-7 & 48.08 & 18.75 & 0.74 & 43.30 \\
\hline
\end{tabular}


Out of twenty entries including local and released varieties of potato all the local accessions were shown maximum resistance (0.10-7.41\% wilt incidence) against bacterial wilt disease. The wilt incidence in IGP 20121 and IGP 2012-5 were recorded $0.10 \%$ and $0.50 \%$, respectively followed by IGP $2012-7$ (0.74\%), IGP 2012-2 (1.48\%), IGP 2012-6 (2.22\%), IGP 2012-3 (6.30\%) and IGP 2012-4 $(7.41 \%)$. Among the released varieties, wilt incidence was ranged from $10.30 \%$ (Kufri Jyoti) to $41.74 \%$ (Kufri Pukhraj).

Among the accessions IGP 2012-2 (10.00\%) shown minimum incidence of viral diseases complex followed by IGP 2012-1 (35.00\%) and IGP 2012-5 (43.20). However, none of the commercial varieties had significant resistance against viral diseases.The resistance recorded in the local accessions can be useful in the local breeding program.

\section{References}

Anonymous. 2017. Overview. Horticulture Statistics at a glance.16

Anonymous. 2017a.

https://www.potatopro.com/world/potat o-statistics

Champoiseau, P.G., Jones, J.B. and Allen. C. 2009. Ralstonia solanacearum race 3 biovar 2 causes tropical losses and temperate anxieties [Online]. Madison: American Phytopathological Society. Available at http://www.apsnet.org/online/feature/ra 1stonia/ (Accessed 25 June 2010).

Champoiseau, P.G., Jones, J.B., Momol, T.M., Pingsheng, J., Allen, C., Norman, D.J. Harmon, C., Miller, S.A., Schubert, T., Bell, D., Floyd, J.P., Kaplan, D., Bulluck, R., Smith, K. and Caldwell K. 2010. Ralstonia solanacearum Race 3 biovar 2 causing brown rot of potato, bacterial wilt of tomato and southern wilt of geranium
[Online]

Kaguongo, W.P., P. Gildemacher, P. Demo, W. Wagoire, P. Kinyae, J. Andrade, G. Forbes, K. Fuglie, and G. Thiele. 2008. Farmer practices and adoption of improved potato varieties in Kenya and Uganda. Social Sciences Working Paper 2008-5. Lima: Centro International de la Papa

Khurana, S.M.P. and Garg, I.D. 1992. Potato mosaic. In Plant disease of international importance. Disease of vegetable and oilseed crops Chaube HS, Singh US, Mukhopadhay AN, Kumar J (Eds), Prentice Hall, New Jersey, USA pp. 148-164.

Khurana, S.M.P. and Singh, M.N. 1988. Yield loss potential of potato virus $\mathrm{X}$ and $\mathrm{Y}$ in Indian potatoes. $J$ Indian Potato Assoc 15: 27-29.

Madison: American Phytopathological Society. Available at http:// plantpath.ifas.ufl.edu/rsol/NRI_Project/ Projectsummary.html (Accessed 25 June 2010)

Muthoni, J., Mbiyu, M.W. and Nyamongo, D.O. 2010. A review of potato seed systems and germplasm conservation in Kenya. Journal of Agricultural and Food Information. 11: 157-167.

Nagaich, B., Shekhawat, G.S., Khuran, S.M. and Bhattacharya, M. 1974. Pathological problems of potato cultivation in India. $J$ Indian Potato Asso 1: 32-44.

Paul S. and Konar, A. 2003. Integrated pest management of aphids of potato in gangetic plains of West Bengal. Proc. Recent Environ. Changes, Impact on Health, Agriculture and Ecosystem. Santa SC (Ed), Univ. Kalyani, WB pp. 26-29.

Smith, J.J., Offord, L.C. Holderness, M. and Saddler. G.S. 1998. The development of biological control against race 3 in Kenya. In Bacterial wilt disease: 
Molecular and ecological aspects. Report of the Second International Wilt Symposium, Gosier, Guadeloupe, France. 22- 27 June 1997, ed. P. Prior et al., 337-342. Berlin: Springer

Tung, P.X. 1992. Genetic variation for bacterial wilt resistance in a population of tetraploid potato. Euphytica. 61: 7380.
Uniyal, J.P. 2003. Production and utilization of True Potato Seeds (TPS). In: Potato cultivation in North Eastern India. Singh PH, Chandla PH, Paul Khurana SM, Garg ID, Thakur KC, et al., (Eds) Central Potato Research Institute, Shimla pp. 11-23.

\section{How to cite this article:}

Pravin Kumar Sharma and Narendra Lakpale. 2020. Diseases Resistance in Potato: Genetic Resources Respond to Bacterial Wilt and Viral Diseases Complex. Int.J.Curr.Microbiol.App.Sci. 9(04): 1846-1850. doi: https://doi.org/10.20546/ijcmas.2020.904.216 